DOI https://doi.org/10.17308/vsu.proc.law.2021.1/3280

\title{
ЮРИДИЧЕСКИЕ ПРИЗНАКИ ИНСТИТУТА РАЗВИТИЯ КАК СУБЪЕКТА ФИНАНСОВОГО ПРАВА
}

\author{
К. И. Брыкин \\ Московский государственный университет илени М. В. Ломоносова \\ Поступила в редакцию 29 июня 2020 г.
}

\begin{abstract}
Аннотация: статья посвящена исследованию юридических признаков такого субъекта фбинансового права, как институт развития. Делается вывод о тол, что институты развития обладают как общили признакали, характерныли для любого иного юридического лица, так и специальнылии. Рассмотрень различия между институтали развития и юридическили лицали публичного права, отдельные признаки которых характерны для институтов развития. Автором отлечается родовая связь между государством и институтол развития, что определяет первичность публично-правового регулирования института развития. Предлагается выделять среди спеииальных признаков институтов развития облзательнье и опииональные признаки.
\end{abstract}

Ключевые слова: институт развития, признаки юридических лии, юридические лииа публичного права, публичные фбункиии, меры государственной поддержки, внешний контроль.

Abstract: the article deals with the study of legal features of such a subject of financial law as a development institution. The conclusion is made that development institutions possess both common features characteristic of any other legal entity and special features. The article discusses the differences between development institutions and legal entities of public law, some features of which are characteristic of development institutions. The author notes the patrimonial relationship between the state and the development institution, which determines the primacy of the public law regulation of the development institution, and it is proposed to distinguish among the special features of development institutions mandatory and optional features.

Key words: development institute, signs of legal entities, legal entities of public law, public functions, state support measures, external control.

Ранее проведенные исследования подходов к определению понятия «институт развития» ${ }^{1}$ позволяют определить его в широком и узком аспекте.

В широком аспекте институт развития - инструмент реализации государственной политики в социально-экономической сфрере путем создания условий для экономического роста и обеспечения модернизации экономики, стимулирования деятельности экономических субъектов. В широ-

${ }^{1}$ См.: Брыкин К. И. Подходы к определению понятия «институт развития» : финансово-правовой аспект // Вестник Моск. ун-та. Серия 26, Государственный аудит. 2019. № 2. С. 49-57.

(C) Брыкин К. И., 2021 


\section{Вестник ВГУ. Серия: Право}

ком аспекте к институтам развития можно отнести юридические лица, публично-правовые образования, территории, в частности особые экономические зоны ${ }^{2}$, территории опережающего социально-экономического развития ${ }^{3}$, свободный порт Владивосток ${ }^{4}$.

В узком аспекте институт развития представляет собой самостоятельный субъект финансового права - коммерческую или некоммерческую организацию, созданную и регулируемую специальными нормативными правовыми актами, которая в рамках достижения целей деятельности, направленных на реализацию государственной социально-экономической политики и выполнения делегированных государством функций, обладает статусом получателя мер государственной поддержки и осуществляет публичную финансовую деятельность.

Институты развития обладают как общими признаками, характерными для любого иного юридического лица, так и специальными.

К общим признакам юридических лиц законодатель в ст. 48 Гражданского кодекса $Р \Phi^{5}$ относит возможность: признания организацией (одной из организационно-правовых фрорм, предусмотренных гражданским законодательством) наличия обособленного имущества; отвечать своим обособленным имуществом по своим обязательствам; от своего имени приобретать и осуществлять гражданские права и нести гражданские обязанности; быть истцом и ответчиком в суде; фракт регистрации в установленном порядке (регистрация в едином государственном реестре юридических лиц).

В доктрине к признакам юридического лица как субъекта гражданского права относятся также следующие признаки ${ }^{6}$ наименование юридического лица, место нахождения и адрес юридического лица, способность иметь гражданские права и обязанности.

А. А. Мохов, анализируя различные теории юридического лица (теории фрикции, корпоративного права, коллектива, социальных связей, функциональных систем), дополнительно отмечает, что «для любой организации характерно: наличие цели и задач, ради достижения которых она создана; наличие группы людей (исполнителей и руководителей),

${ }^{2}$ Об особых экономических зонах в Российской Федерации : фредер. закон от 22 июля 2005 г. № 116-ФЗ // Собр. законодательства Рос. Федерации. 2005. № 30 (ч. 2). Ст. 3127.

${ }^{3} \mathrm{O}$ территориях опережающего социально-экономического развития в Российской Федерации : федер. закон от 29 декабря 2014 г. № 473-ФЗ // Собр. законодательства Рос. Федерации. 2015. № 1 (ч. 1). Ст. 26.

${ }^{4} \mathrm{O}$ свободном порте Владивосток : фредер. закон от 13 июля 2015 г. № 212-ФЗ // Собр. законодательства Рос. Федерации. 2015. № 29 (ч. 1). Ст. 4338.

${ }^{5}$ Гражданский кодекс Российской Федерации (часть первая) : феедер. закон от 30 ноября 1994 г. № 51-ФЗ // Собр. законодательства Рос. Федерации. 1994. № 32. Ст. 3301.

${ }^{6}$ См.: Корпоративное право : учебник / А. В. Габов [и др.] ; отв. ред. И. С. Шиткина. М., 2019. 
действия которых направлены на достижение поставленной цели и задач» ${ }^{7}$.

Стоит также обратить внимание на иную группу юридических лиц юридические лица публичного права. Признаками, отличающими юридические лица публичного права от обычных юридических лиц, Е. А. Суханов называет: «наличие властного акта или специального закона, на базе которого возникло и действует такое юридическое лицо; публичные (общественные или государственные), «идеальные» (а не коммерческие) цели и задачи деятельности, наличие которых сближает его с некоммерческими организациями; наличие у такой организации некоторых властных полномочий (или «принудительных средств») в отношении третьих лиц, которые могут, но не обязаны использоваться; возможность создания такого юридического лица только публично-правовым образованием, а не гражданами или обычными юридическими лицами; невозможность его реорганизации (преобразования) в юридическое лицо частного права; судебная оценка совершаемых им сделок с позиций известной доктрины ultra vires (т. е. признание за ним строго целевой, а не общей правоспособности); особый порядок обращения взыскания на его имущество по его долгам; невозможность банкротства такого юридического лица»8.

Все в совокупности признаки юридических лиц публичного права не могут быть применены к институтам развития 9 . Это подчеркивает самостоятельность институтов развития и их отличие от юридических лиц публичного права. Однако некоторые из названных признаков характерны и для институтов развития.

Переходя к анализу специальных признаков институтов развития, стоит отметить, что в п. 3 Правил оценки эффрективности, особенностей определения целевого характера использования бюджетных средств, направленных на государственную поддержку инновационной деятельности, а также средств из внебюджетных источников, возврат которых обеспечен государственными гарантиями, и применяемых при проведении такой оценки критериев ${ }^{10}$, содержится определение термина «институт инновационного развития», который определен как «созданная (в том

${ }^{7}$ Мохов А. А. Юридическое лицо как функциональная система // Гражданское право. 2015. № 4. С. 21-24.

${ }^{8}$ Суханов E. A. Сравнительное корпоративное право. М., 2014.

9 Так, в соответствии с ч. 13 ст. 25.1 Федерального закона от 24 июля 2007 г. № 209-ФЗ «О развитии малого и среднего предпринимательства в Российской Федерации» корпорация развития малого и среднего предпринимательства может быть реорганизована или ликвидирована на основании федерального закона, определяющего цели, порядок и сроки реорганизации или ликвидации корпорации развития малого и среднего предпринимательства и судьбу имущества, находящегося в ее собственности.

${ }^{10}$ Об утверждении Правил оценки эффективности, особенностей определения целевого характера использования бюджетных средств, направленных на государственную поддержку инновационной деятельности, а также средств из внебюджетных источников, возврат которых обеспечен государственными гарантиями, и применяемых при проведении такой оценки критериев : постановление 


\section{Вестник ВГУ. Серия: Право}

числе путем реорганизации) и (или) осуществляющая деятельность на основании фредерального закона, указа или распоряжения Президента Российской Федерации, акта Правительства Российской Федерации, закона или иного нормативного правового акта субъекта Российской Федерации коммерческая или некоммерческая организация (ее правопреемник), являющаяся получателем средств государственной поддержки в допускаемой законодательством Российской Федерации форме и самостоятельно осуществляющая инновационную деятельность и (или) являющаяся субъектом инновационной деятельности, которой Российской Федерацией или субъектами Российской Федерации предоставляются средства на оказание поддержки юридических и фризических лиц, осуществляющих инновационную деятельность».

Исходя из указанного определения, можно выделить следующие признаки института инновационного развития:

1) коммерческая или некоммерческая организация (ее правопреемник);

2) создан (в том числе путем реорганизации) и (или) осуществляет деятельность на основании федерального закона, указа или распоряжения Президента РФ, акта Правительства РФ, закона или иного нормативного правового акта субъекта РФ;

3) является получателем средств государственной поддержки в допускаемой законодательством Российской Федерации форме;

4) самостоятельно осуществляет инновационную деятельность и (или) является субъектом инновационной деятельности, которому Российской Федерацией или субъектами РФ предоставляются средства на оказание поддержки юридических и физических лиц, осуществляющих инновационную деятельность.

Полагаем, что названные признаки «института инновационного развития» можно разделить на характерные для любого института развития и исключительные признаки институтов инновационного развития.

К первой группе признаков, которые характерны для любого института развития, предлагается отнести первые три из вышеназванных. Так, ДОМ.РФ (единый институт развития в жилищной сорере) создан в форме коммерческой организации (акционерного общества), а ВЭБ.РФ - некоммерческой организации (государственная корпорация). Обе организации осуществляют свою деятельность на основании специальных федеральных законов, которыми предусмотрено оказание данным институтам развития мер государственной поддержки.

Исключительным признаком института инновационного развития является последний - самостоятельно осуществляет инновационную деятельность и (или) является субъектом инновационной деятельности, которому Российской Федерацией или субъектами РФ предоставляются средства на оказание поддержки юридических и фризических лиц, осу-

Правительства РФ от 31 марта 2018 г. № 392 // Собр. законодательства Рос. Федерации. 2018. № 15 (ч. 5). Ст. 2158. 
ществляющих инновационную деятельность. В данном случае критерий, на основании которого данный признак определен в качестве исключительного, является сфера деятельности, а именно инновационная деятельность.

Хочется обратить внимание на исследование А. А. Кузнецова, в котором проведен подробный исторический анализ предпосылок императивности корпоративного законодательства ${ }^{11}$. Автор отмечает, что первые колониальные компании (Ост-Индская и др.) создавались «специальным актом (octori), которым государство даровало правосубъектность и привилегию ограниченной ответственности. При этом регулирование колониальных компаний, по существу, было частью публичного права, так как такие компании представляли собой продолжение государственной власти, отсюда более чем подробное регулирование их деятельности, вплоть до того, что решения о выплате дивидендов, принятии новых акционеров и т. п. принималось посредством законодательных актов». Следующим историческим этапом был концессионный порядок «создания акционерных обществ, неотъемлемой чертой которых были «привилегия» ограниченной ответственности и свободная продажа акций». На рубеже XVIII и XIX вв. старая система была отменена, но сохранился разрешительный порядок учреждения, «компания создавалась после одобрения государства». После отмены разрешительной системы «европейские государства смогли сохранить часть своего былого влияния за счет жесткой императивности законов, регулирующих порядок создания и деятельности обществ». А. А. Кузнецов приходит к выводу о «родовой связи коммерческих обществ (АО и ООО) с государством, несущей в себе печать дозволения» ${ }^{12}$.

Названная «родовая связь» с государством и регулирование публичным правом непосредственно прослеживается в регулировании институтов развития и проявляется в следующих обязательных специальных признаках институтов развития:

- создаются и регулируются специальными нормативными правовыми актами, о которых ранее шла речь; ции ${ }^{13}$;

- институтам развития делегируются отдельные публичные фрунк-

${ }^{11}$ См.: Кузнецов А. А. Пределы автономии воли в корпоративном праве : краткий очерк. М., 2017.

12 Там же.

13 Так, в соответствии с ч. 2.1 ст. 3 Федеральный закон от 24 июля 2008 г. № 161-ФЗ «О содействии развитию жилищного строительства» в целях, предусмотренных названным федеральным законом, единый институт развития выступает агентом Российской Федерации и от своего имени совершает юридические и иные действия, в том числе сделки, с находящимися в федеральной собственности земельными участками и иными объектами недвижимого имущества, предусмотренных ст. 11 названного федерального закона другим имуществом, в отношении которых уполномоченным Правительством РФ межведомственным коллегиальным органом принято предусмотренное п. 2 ч. 1 ст. 12 названного Федерального закона решение. Согласно ч. 26 ст. 46.1 Федерального закона от 8 декабря 2003 г. № 164-Ф3 «Об основах государственного регулирования внеш- 
- приоритет целей деятельности института развития, направленных на реализацию государственной политики, над коммерческими (предпринимательскими) целями ${ }^{14}$;

- институтам развития оказываются меры государственной поддержки, которые регулируются публичными отраслями права ${ }^{15}$;

- над институтами развития осуществляется особый внешний контроль, в том числе путем избрания и (или) назначения органов управления института развития публично-правовым образованием в лице уполномоченных органов государственной власти и их должностных лиц ${ }^{16}$;

неторговой деятельности» Российский экспортный центр, акционерное общество «Российское агентство по страхованию экспортных кредитов и инвестиций», Государственный специализированный Российский экспортно-импортный банк (акционерное общество) вправе в порядке, устанавливаемом Правительством РФ, выступать агентами Правительства РФ по вопросам реализации мер государственной поддержки экспорта.

${ }^{14}$ Например, согласно ч. 1 и 2 ст. 3 Федерального закона от 17 мая 2007 г. № 82-ФЗ «О государственной корпорации развития «ВЭБ.РФ» ВЭБ.РФ действует в целях содействия в обеспечении долгосрочного социально-экономического развития Российской Федерации и создании условий для устойчивого экономического роста, повышения эффективности инвестиционной деятельности и расширения инвестирования средств в национальную экономику посредством реализации проектов в Российской Федерации и за рубежом, в том числе с участием иностранного капитала, направленных на развитие инфраструктуры, промышленности, инноваций, особых экономических зон, защиту окружающей среды, повышение энергоэффрективности, поддержку экспорта и расширение доступа российской промышленной продукции (товаров, работ, услуг) на зарубежные рынки, а также иных проектов и (или) сделок в рамках осуществления инвестиционной, внешнеэкономической, консультационной и иной предусмотренной настоящим феде- ральным законом деятельности; при этом ВЭБ.РФ вправе осуществлять предпри이 нимательскую деятельность лишь постольку, поскольку это служит достижению названных целей и соответствует этим целям. Прибыль ВЭБ.РФ, полученная по результатам его деятельности, направляется в фонды ВЭБ.РФ и используется исключительно для достижения названных целей.

15 Так, в соответствии с ч. 7 ст. 2 Федерального закона от 13 июля 2015 г. № 225-Ф3 «О содействии развитию и повышению әффрективности управления в

216 жилищной сфере и о внесении изменений в отдельные законодательные акты Российской Федерации» единому институту развития в жилищной сфрере для решения задач и осуществления фрункций, предусмотренных названной статьей, предоставляется государственная поддержка в соответствии с бюджетным законодательством Российской Федерации.

${ }_{16}$ Так, согласно ч. 2 ст. 25.2 Федерального закона от 24 июля 2007 г. № 209Ф3 «О развитии малого и среднего предпринимательства в Российской Федерации» совет директоров корпорации развития малого и среднего предпринимательства формируется Правительством РФ в количестве одиннадцати членов. Председатель совета директоров корпорации развития малого и среднего предпринимательства, члены совета директоров корпорации развития малого и среднего предпринимательства назначаются на должность на неопределенный срок и освобождаются от должности Правительством РФ. В соответствии с ч. 2 ст. 15 Закона о ВЭБ.РФ председатель ВЭБ.РФ назначается на должность и освобождается 
- институты развития имеют специальное правовое регулирование ${ }^{17}$. Помимо обязательных специальных признаков институтов развития предлагается также выделить опииональные специальные признаки:

- в наименования институтов развития допускается включение официального наименования «Российская Федерация» или «Россия», а также слов, производных от этого наименования ${ }^{18}$; тия ${ }^{19}$;

- особый порядок реорганизации и ликвидации институтов разви-

- наличие специальных требований к финансовой устойчивости институтов развития ${ }^{20}$.

Институты развития, как и все юридические лица, обладают рядом общих признаков, установленных гражданским законодательством. При

от должности Президентом РФ. Председатель ВЭБ.РФ назначается на должность по представлению Председателя Правительства РФ.

17 Так, согласно ч. 23 ст. 46.1 Федерального закона от 8 декабря 2003 г. № 164ФЗ «Об основах государственного регулирования внешнеторговой деятельности» на акционерное общество «Российское агентство по страхованию экспортных кредитов и инвестиций» не распространяются положения законодательства Российской Федерации об организации страхового дела, названное общество осуществляет деятельность по страхованию экспортных кредитов и инвестиций без получения разрешения (лицензии).

${ }^{18}$ Согласно ч. 30 ст. 46.1 Федерального закона от 8 декабря 2003 г. № 164-Ф3 «Об основах государственного регулирования внешнеторговой деятельности», ч. 9 ст. 2 Федерального закона от 13 июля 2015 г. № 225-ФЗ «О содействии развитию и повышению эффрективности управления в жилищной сфере и о внесении изменений в отдельные законодательные акты Российской Федерации» допускается включение официального наименования «Российская Федерация» или «Россия», а также слов, производных от этого наименования, в наименования Российского экспортного центра, акционерного общества «Российское агентство по страхованию экспортных кредитов и инвестиций» и Государственного специализированного Российского экспортно-импортного банка (акционерное общество), а также в фирменные наименования единого института развития в жилищной сфрере, его организаций и иных юридических лиц, признаваемых в соответствии с законодательством Российской Федерации подконтрольными лицами единого института развития в жилищной сфрере.

${ }^{19}$ В соответствии со ст. 6 Федерального закона от 13 июля 2015 г. № 225-ФЗ «О содействии развитию и повышению эффективности управления в жилищной сфере и о внесении изменений в отдельные законодательные акты Российской Федерации» реорганизация, ликвидация единого института развития в жилищной сфере допускаются только на основании федерального закона о реорганизации, ликвидации. $\mathrm{K}$ процедуре ликвидации единого института развития в жилищной сфрере не применяются правила, предусмотренные Федеральным законом от 26 октября 2002 г. № 127-ФЗ «О несостоятельности (банкротстве)».

${ }^{20} \mathrm{~B}$ соответствии с п. 60 Меморандума о фринансовой политике государственной корпорации «Банк развития и внешнеәкономической деятельности (Внешэкономбанк)», утвержденного распоряжением Правительства РФ от 23 июля 2018 г. № 1510-р, при осуществлении своей деятельности Внешэкономбанк обеспечивает соблюдение минимально допустимого уровня коэфффициента достаточности капитала в размере 10 процентов. 


\section{Вестник ВГУ. Серия: Право}

этом проведенный анализ нормативных правовых актов и научных подходов позволил выявить обязательные и опциональные специальные признаки, указывающие на первичную публично-правовую природу институтов развития и их самостоятельность как субъектов фринансового права.

Московский государственный университет илени М. В. Лолоносова

Брыкин К. И., аспирант кафбедры правовых дисииплин

E-mail:BrykinKI.veb@gmail.com
Lomonosov Moscow State University

Brykin K. I., Post-graduate Student of the Legal Disciplines Department

E-mail:BrykinKI.veb@gmail.com 